\title{
Genetic Analysis of Fiber Traits in Cotton
}

\author{
Yüksel BÖLEK $^{1}$, Hatice ÇOKKIZGIN ${ }^{2 *}$, Adem BARDAK ${ }^{1}$ \\ ${ }^{1}$ KSU, Faculty of Agriculture, Department of Agricultural Biotechnology, Kahramanmaraş \\ ${ }^{2}$ Gaziantep University, Nurdağı Vocational School, Gaziantep
}

Received (Geliş): 07.03.2013

Accepted (Kabul): 21.03.2014

\begin{abstract}
Diallel analysis has been used in many breeding programs to increase yield and quality. Eight cotton genotypes (Giza-45, Aşkabat-100, Is-4, 108-F, Acala Prema, Çukurova-1518, Nazilli-84S, Stoneville-45) were crossed in a complete diallel design in Kahramanmaraş in 2007. Genetic characteristics for fiber quality traits; length (Len), strength (Str), micronaire (Mic), uniformity (Unf), elongation (Elg), spinning consistency index (Sci) and short fiber index (Sfi) were determined through Hayman-Jinks diallel analysis methods. The analysis of variance revealed significant differences among the parents. Inheritances of most of the characters were due to dominant genes that were determined for Len, Mic, Sci, Str in Is-4; for Sfi and Unf in Giza-45 and for Elg in Nazilli 84S.
\end{abstract}

Key Words: Fiber quality, gene action, cotton, diallel

\section{Pamukta Lif Özelliklerinin Genetik Analizi}

Özet: Diallel analiz yöntemi verim ve kaliteyi artırmak için birçok 1slah programında kullanılmaktadır. Sekiz pamuk genotipi (Giza-45, Aşkabat-100, Is-4, 108-F, Acala Prema, Çukurova-1518, Nazilli-84S, Stoneville-45) 2007 yılında Kahramanmaraş'ta tam diallel dizayna uygun olarak melezlenmiştir. Lif kalite karakterleri; uzunluk (Len), dayanıklılık (Str), incelik (Mic), üniformite (Unf), uzama (Elg), iplik olabilirlik indeksi (Sci) ve kısa lif indeksi (Sfi) için genetik özellikler Hayman-Jinks diallel analiz yöntemine göre belirlenmiştir. Varyans analizi ebeveynler arasında önemli farklılıklar ortaya çıkartmıştır. Is-4'te Len, Mic, Sci, Str için; Giza-45'te Sfi ve Unf için; Nazilli 84S'de Elg için dominant genler belirlenmiştir.

Anahtar Kelimeler: Lif kalitesi, gen hareketi, pamuk, diallel

\section{INTRODUCTION}

The knowledge of genetic structure and mode of inheritance of complex traits help breeders and producers to establish suitable breeding methodology to improve economically important traits (Garg and Kalsy, 1988). Selection criteria have been used in conventional breeding programs are usually based on phenotypic characteristics. Recently, molecular markers started to employ in breeding programs. On the other hand, environmental conditions affect the phenotypic characteristics that have polygenic nature (Antoni et al., 1991; Rivera et al., 1999). Also, it is difficult to characterize with morphological markers and they don't show high levels of variation (Lukonge, 2005). Repeated crossing and intensive selection between a few genotypes with desirable traits, led to the narrowing of the cotton gene pool that resulted in low genetic variation of cultivated cotton genotypes. It is needed to include new and diverse progenitors in the breeding programs from other species such as G. barbadense and wild type accessions to increase variability.

It is necessary to characterize the genetic structure of every breeding material for effective breeding scheme. Diallel analysis method was developed to have an idea about the genetic mechanisms and structure of populations for different traits (Hayman, 1954). The breeding programs for many crops use diallel analysis because it offers genetic information on quantitative traits to the breeders (Viana et al., 2001; Peyman, 2012; Akbari et al., 2013). Diallel analysis also gives information about good combining inbred lines suitable for hybrid production (Ado et al., 2006; Townsend et al., 2013). It is a strong technique to explain differences of genotypes, phenotypic variance, additive gene effects, variation ratio of specific gene combinations (Danehloueipour et al., 2007; Saleem et al., 2013). It also provides useful data about genetic control of quantitative traits and their gene effects model (Baker, 1978; Yao et al., 2011). This way, dominant parents and hybrids can be defined (Goyal and Kumar, 1991; Ahuja and Dhayal, 2007). On the other hand, diallel analysis has been used for genetic control study of quantitative traits of autogam or allogam populations (Jinks and Hayman, 1953), study of general and specific combining ability (Griffing, 1956) and analysis of heterosis (Gardner and Eberhart, 1966). Diallel crossing technique in cotton has also been used by cotton breeders (Zangi et al., 2010) and it explains practical and important information about breeder's materials (Ali et al., 2011). With this, it also reports equality and distribution of dominant and recessive alleles (Mohamed et al., 2009) as well as better genotypes for whichever yield trait (Ragsdale, 2003).

Cheatham et al. (2003) reported that Australian and wild cotton genotypes have the genes to improve fiber quality and fertility. While fiber fineness and length 
primarily exhibit dominance gene effects, fiber percentage and fiber strength are controlled by additive gene effects. On the other hand, fiber yield and fiber elongation extension are controlled equally by additive and dominant gene effects. Thus there is a need an effective characterization of germplasm for successful cotton breeding. The purpose of this work is to identify gene action of some fiber quality traits in cotton cultivars mostly used in crosses to develop high yielding quality cotton.

\section{MATERIAL and METHODS}

Plant material: Eight cotton genotypes were used in the experiment. They were belonging to G. hirsutum L. (Is-4, 108-F, Acala Prema, Çukurova-1518, Nazilli-84S, Stoneville-453) and $G$. barbadense L. (Giza-45, Aşkabat-100) species. Genotypes were selected for important fiber characteristics in addition to verticillium wilt resistance (Table 1).

Table 1. Characteristics of the cotton genotypes used in the experiment

\begin{tabular}{|c|c|}
\hline Genotypes & Characters \\
\hline Giza-45 & $\begin{array}{l}\text { Length }(36.3 \mathrm{~mm}) \text {, strength }(42.7 \mathrm{~g} / \text { tex }) \text {, uniformity }(87.5 \%) \text {, elongation }(6.7 \%) \text {, } \\
\text { spinning consistency index }(215.5) \text {, short fiber index }(3.4) \text { and verticillium wilt } \\
\text { resistance. }\end{array}$ \\
\hline Aşkabat-100 & $\begin{array}{l}\text { Length }(35.6 \mathrm{~mm}) \text {, strength ( } 43 \mathrm{~g} / \mathrm{tex}) \text {, micronaire }(3.4) \text {, uniformity }(85.6 \%) \text {, short fiber } \\
\text { index (3.4) and verticillium wilt resistance. }\end{array}$ \\
\hline Is-4 & $\begin{array}{l}\text { Length }(36.4 \mathrm{~mm}) \text {, strength }(45.1 \mathrm{~g} / \text { tex }) \text {, micronaire }(3.8) \text {, uniformity }(88.1 \%) \text {, spinning } \\
\text { consistency index }(223) \text {, short fiber index (3.4) and verticillium wilt resistance. }\end{array}$ \\
\hline $108-\mathrm{F}$ & $\begin{array}{l}\text { Length }(32 \mathrm{~mm}) \text {, strength }(40.4 \mathrm{~g} / \text { tex }) \text {, uniformity }(87.7 \%) \text {, spinning consistency index } \\
\text { (197.5), short fiber index (3.4) and verticillium wilt resistance. }\end{array}$ \\
\hline Acala Prema & $\begin{array}{l}\text { Strength }(40) \text {, uniformity }(86.7 \%) \text {, spinning consistency index }(188) \text {, short fiber index } \\
\text { (3.4). Acala lines are most widely used in hybridization programs in the world. } \\
\text { Vertcillium resistance and high yielding. }\end{array}$ \\
\hline Çukurova-1518 & $\begin{array}{l}\text { Commercial cultivar developed at Cukurova Agricultural Research Institute. Adapted to } \\
\text { Mediterranean Region of Turkey. High ginning turnout }(41 \%) \text {. }\end{array}$ \\
\hline Nazilli-84S & $\begin{array}{l}\text { Commercial cultivar developed at Nazilli Agricultural Research Institute. Adapted to } \\
\text { Aegean Region of Turkey. High ginning turnout }(45 \%) \text {. }\end{array}$ \\
\hline Stoneville-453 & $\begin{array}{l}\text { Commercial cultivar developed at Stoneville Pedigree in USA. Adapted to Southeast of } \\
\text { Turkey. High ginning turnout }(42 \%) \text {. }\end{array}$ \\
\hline
\end{tabular}

Field evaluations: The $F_{1}$ material was developed by crossing eight cultivars in all possible combinations in the experimental fields of Kahramanmaraş Agricultural Research Institute in 2007. In the experiment, plot length was $12 \mathrm{~m}$, spacing between and within rows was $70 \times 20 \mathrm{~cm}$. Completely randomized block design with 3 replications was applied. Standard cultural practices were applied as fertilizer $(14 \mathrm{~kg} \mathrm{~N}$ and $12 \mathrm{~kg} \mathrm{P}_{2} \mathrm{O}_{5}$ ) and irrigations (total 7-10 times in about 810 days intervals as needed during growing seasons). Field was received total $680.6 \mathrm{~mm}$ amount of rain during 2007 growing season. Bolls were sampled from the first position of the middle fruiting branches of each genotype. Fiber characteristics; length (Len) (mm) (2.5\% Span Length), strength (Str) (g/tex) micronaire (Mic), uniformity (Unf) (\%), elongation (Elg) (\%), spinning consistency index (Sci) and short fiber index (Sfi) were determined by HVI (High Volume Instruments).

Statistical analysis: The data were analyzed using diallel type methods developed by Hayman-Jinks (1953). Parameters calculated are follows: E: Expected environmental component of variation, D: Additive genetic variance, $\mathrm{F}$ : Mean of Fr values over arrays, H1 Variation due to dominant effect of gene, H2: Variation due to dominant effect of gene correlated with gene distribution, KD/KR: Ratio of dominance and recessive allels, $h^{2}$ : Net dominance over all loci in heterozygous phase, K: Effective genes, Wr: Co-variance, Vr: Variance, Hg: Broad sense heritability, Hd: Narrow sense heritability.

\section{RESULTS and DISCUSSION}

The results for the analysis of variance revealed that the mean genetic differences among the hybrids and their parents in $F_{1}$ generation were highly significant for all the fiber characters studied (Table 2).

Diallel analysis showed for all traits (H1/D) ${ }^{1 / 2}$ value greater than 1 (Table 3 ). Therefore, there is overdominance for the traits because in a diallel analysis, if (H1/D) ${ }^{1 / 2}$ value greater than 1 , there is over-dominance for the trait (Balc1 and Turgut, 2006). Thus, in hybrid studies there may be a high chance of success in selecting superior genotypes. On the other hand, variation in environment can effect plant development and growth as well as quality of the product. If environmental variance is high then breeding can result unsuccessfully (Şener et al., 1999). Because of environmental variance is too high $(30.539 \pm 148.093)$ for Sci in this experiment, breeding studies may be unsuccessful for this trait. Additionally, 
$\mathrm{KD} / \mathrm{KR}$ ratio less than 1 , meaning that recessive genes are excess for Sci (Table 3).

Table 2. Analysis of variance for parents and $F_{1} s$

\begin{tabular}{lll}
\hline Characters & Mean Squares & $\mathrm{F}$ \\
\hline Micronaire & 0.318 & $38.585^{*}$ \\
Length $(\mathrm{mm})$ & 22.028 & $23.451^{*}$ \\
Strength $(\mathrm{g} / \mathrm{tex})$ & 54.216 & $17.873^{*}$ \\
Spinning consistency index & 1669.603 & $28.247^{*}$ \\
Uniformity (\%) & 4.981 & $6.333^{*}$ \\
Short fiber index & 0.454 & $7.546^{*}$ \\
Elongation $(\%)$ & 0.832 & $7.754^{*}$ \\
\hline
\end{tabular}

*, Significant at 0.05

Table 3. Some genetic parameters for the fiber characters studied

\begin{tabular}{llllllll}
\hline $\begin{array}{l}\text { Source of } \\
\text { Variation }\end{array}$ & Micronaire & Length $(\mathrm{mm})$ & Strength $(\mathrm{g} / \mathrm{tex})$ & Spinning consistency index & Uniformity $(\%)$ & Short fiber index & Elongation $(\%)$ \\
\hline $\mathrm{E}$ & $0.004 \pm 0.025$ & $0.472 \pm 0.845$ & $1.493 \pm 5.280$ & $30.539 \pm 148.093$ & $0.445 \pm 0.738$ & $0.040 \pm 0.043$ & $0.058 \pm 0.079$ \\
\hline $\mathrm{D}$ & $0.239 \pm 0.076$ & $12.208 \pm 2.536$ & $16.402 \pm 15.840$ & $376.559 \pm 444.279$ & $1.810 \pm 2.213$ & $0.168 \pm 0.129$ & $0.710 \pm 0.236$ \\
\hline $\mathrm{F}$ & $0.376 \pm 0.180$ & $-3.624 \pm 5.993$ & $8.091 \pm 37.428$ & $-328.076 \pm 1,049.791$ & $2.337 \pm 5.228$ & $0.119 \pm 0.304$ & $1.070 \pm 0.557$ \\
\hline $\mathrm{H} 1$ & $0.771 \pm 0.175$ & $18.899 \pm 5.831$ & $103.062 \pm 36.413$ & $2,213.187 \pm 1,021.332$ & $10.128 \pm 5.086$ & $0.744 \pm 0.296$ & $1.945 \pm 0.542$ \\
\hline $\mathrm{H} 2$ & $0.606 \pm 0.152$ & $30.141 \pm 5.073$ & $105.893 \pm 31.679$ & $2,651.975 \pm 888.558$ & $8.424 \pm 4.425$ & $0.672 \pm 0.257$ & $1.408 \pm 0.472$ \\
\hline $\mathrm{D}-\mathrm{H} 1$ & $-0.533 \pm 0.150$ & $-6.691 \pm 5.003$ & $-86.659 \pm 31.243$ & $-1,836.628 \pm 876.326$ & $-8.318 \pm 4.364$ & $-0.577 \pm 0.254$ & $-1.235 \pm 0.465$ \\
\hline$(\mathrm{H} 1 / \mathrm{D})^{1 / 2}$ & 1.798 & 1.244 & 2.507 & 2.424 & 2.365 & 2.107 & 1.656 \\
\hline $\mathrm{H} 2 / 4 \mathrm{H} 1$ & 0.196 & 0.399 & 0.257 & 0.300 & 0.208 & 0.226 & 0.181 \\
\hline $\mathrm{KD} / \mathrm{KR}$ & 2.561 & 0.787 & 1.218 & 0.695 & 1.751 & 1.403 & 2.673 \\
\hline $\mathrm{h}^{2}$ & $-0.002 \pm 0.102$ & $5.998 \pm 3.402$ & $33.899 \pm 21.246$ & $922.617 \pm 595.905$ & $1.219 \pm 2.968$ & $0.234 \pm 0.173$ & $0.607 \pm 0.316$ \\
\hline $\mathrm{K}$ & -0.003 & 0.199 & 0.320 & 0.348 & 0.145 & 0.348 & 0.431 \\
\hline $\mathrm{Yr}, \mathrm{Wr}+\mathrm{Vr}$ for r & -0.072 & -0.878 & 0.678 & -0.264 & -0.814 & 0.787 & 0.214 \\
\hline $\mathrm{Hg}$ & 0.773 & 0.829 & 0.647 & 0.813 & 0.570 & 0.600 & 0.601 \\
\hline $\mathrm{Hd}$ & 0.367 & 0.333 & 0.140 & 0.124 & 0.159 & 0.176 & 0.390 \\
\hline $\mathrm{E}: \mathrm{Expected}$
\end{tabular}

E: Expected environmental component of variation, D: Additive genetic variance, F: Mean of Fr values over arrays, H1: Variation due to dominant effect of gene, H2: Variation due to dominant effect of gene correlated with gene distribution, KD/KR: Ratio of dominance and recessive alleles, $\mathrm{h}^{2}$ : Net dominance over all loci in heterozygous phase, K: Effective genes, Wr: Co-variance, Vr: Variance, Hg: Broad sense heritability, Hd: Narrow sense heritability

In Wr-Vr graphs (Figure 1), co-variance and variance points show parents. If this points away from the regression line, there is epistatic gene effect otherwise if these points near origin and regression line, there are more dominant genes (Yıldırım, 2005). The inheritance of Sci is shown in a $\mathrm{Wr}-\mathrm{Vr}$ graph in Figure 1. With regard to Sci, the parents; Aşkabat-100 (2) and Is-4 (3) had more dominant genes whereas Giza-45 (1), 108-F (4), Acala Prema (5), Çukurova1518 (6), Nazilli-84S (7) and Stoneville-453 (8) carried more recessive genes. Stoneville-453 (8) for Elg, Len, Mic, Sfi and Unf; Çukurova-1518 (6) for Elg, Len, Mic; Giza-45 (1) for Sci and 108-F (4) for Str have more recessive genes than other parents. Moreover, Is-4 (3) for Len, Mic, Sci and Str; Nazilli84-S (7) for Elg; Aşkabat-100 (2) for Sci and Sfi; Giza-45 (1), 108-F (4) and Çukurova-1518 (6) for Unf have more dominant genes than the other parents. In a study, Ali et al. (2008) determined that parents have more dominant genes than recessive genes for the traits; Len, Str, Unf and Elg. When genotypes close to the regression line it could be postulated that there is no epistatic gene effect for the traits but genotypes away from the parabola indicates more recessive gene action. Analysis showed that Acala Prema was away from the regression line for all the traits. This result indicates Acala Prema have epistatic gene effect for all the traits. There is no epistatic gene effect for the genotypes near the regression line. If regression line cut the $\mathrm{Wr}$ axis above the origin, there is partial dominance and if regression line cut the $\mathrm{Wr}$ axis below the origin, there is over-dominance (Hayman, 1954). Griffing analysis describes partial-dominance for Str, but over-dominance was also present for all the traits except Sci and Str (Table 3). 
0.44

000

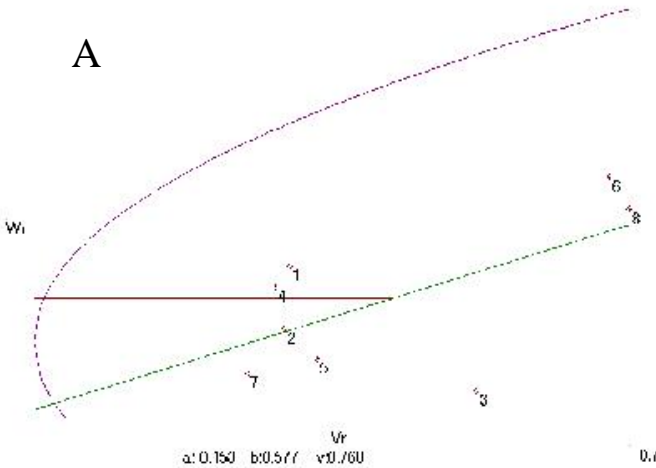

n.95
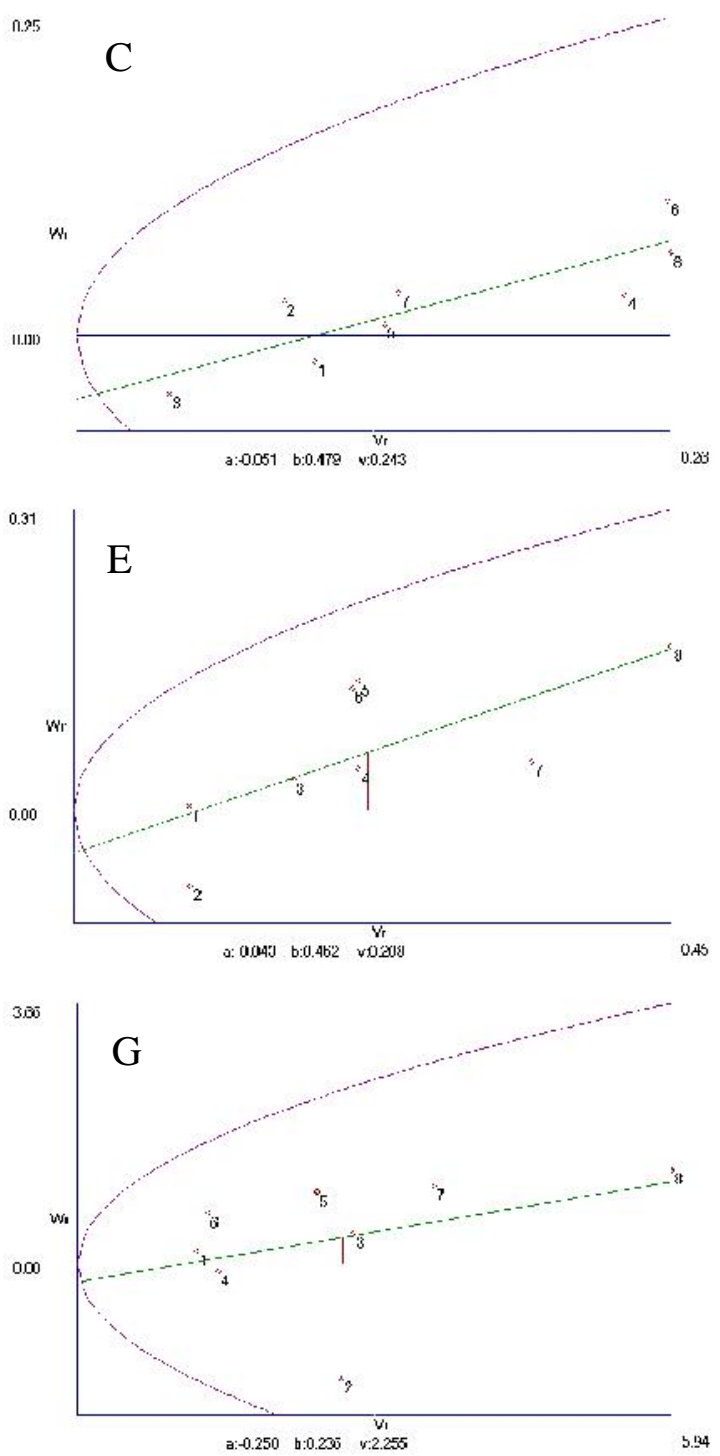

13.55

$n .00$

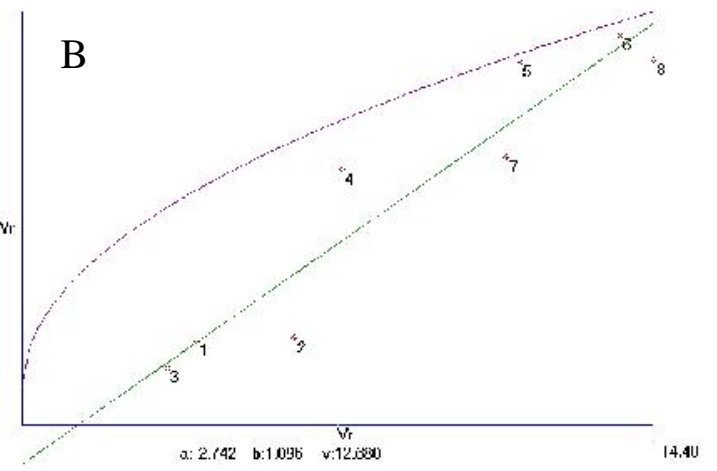

T3111

D

0.00

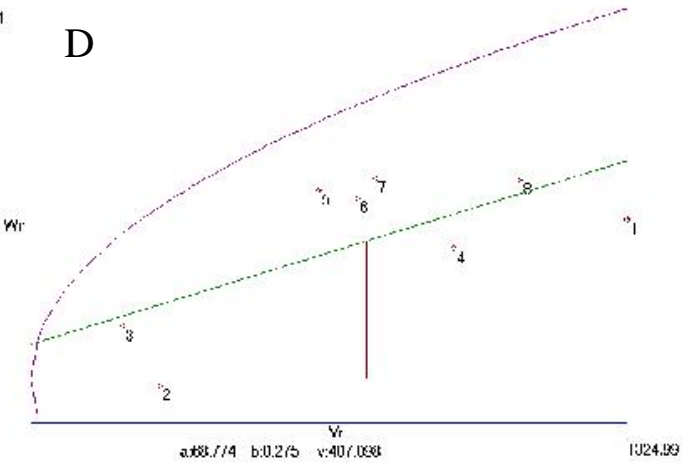

S0A 5

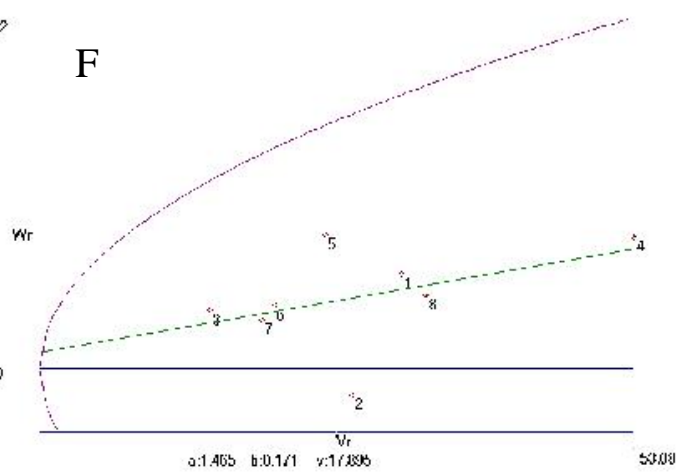

Figure 1. Vr-Wr graphs for fiber elongation (A), length (B), micronaire (C), spinning consistency index (D), short fiber index (E), strength (F), and uniformity (G). Parents were shown in numbers (1: Giza-45, 2: Aşkabat-100, 3: Is4, 4: 108-F, 5: Acala Prema, 6: Çukurova-1518, 7: Nazilli-84S, 8: Stoneville-453)

D-H1 had negative values for all the traits (Table 3). This shows that dominant gene effect have more important role than additive effect in the formation of the traits. This result is parallel with additive and nonadditive genes are important (Pole et al., 2008) for Len,
Str, Mic traits (Rauf et al., 2006). Aguiar et al. (2007) indicated most of micronaire index, fiber strength, fiber length, uniformity index, short-fiber index and fiber elongation traits were affected by additive genes. H2/4H1 unequal 0.25 for all traits except Str (Table 3) 
indicating that dominant and recessive genes unequal (Şener et al., 2000). Str was near to 0.25 meaning it has equal allel frequency. Therefore, breeding will have a high success for Str (Ragsdale, 2003). Additionally, $\mathrm{H} 1>\mathrm{H} 2$ indicates that allelic frequency unequal for Mic, Unf, Sfi, Elg (Table 3). This result was also supported by $\mathrm{H} 2 / 4 \mathrm{H} 1$ ratio that was less than 0.25 . KD/KR ratio was higher than 1 for all traits except Len and Sci (Table 3). Therefore, there are dominant genes more than recessive genes in population for the traits. Effective gene was not determined because of $\mathrm{K}$ (effective gene) less than 1 for all traits.

Karademir and Gençer (2010) reported that ginning percentage, fiber length, fiber fineness and fiber elongation properties were influenced by additive while seed cotton yield, fiber strength and fiber uniformity ratio were influenced by non-additive gene effects in the experimental populations. Positive $\mathrm{r}$ for $\mathrm{Yr}, \mathrm{Wr}+\mathrm{Vr}$ indicates that parents with higher values for Str, Sfi and Elg have recessive alleles but dominant alleles have negative effect for the same characters. On the other hand, negative $\mathrm{r}$ for $\mathrm{Yr}, \mathrm{Wr}+\mathrm{Vr}$ indicates that parents with higher values for Mic, Len, Sci, Unf have dominant genes and the alleles increasing these values are also dominant. $\mathrm{H} 2 / 4 \mathrm{H} 1$ ratios less than 1 and $\mathrm{KD} / \mathrm{KR}$ ratios bigger than 1 except Len and Sci shows that parents have dominant gene frequency more than recessive gene frequency for all the traits (Table 3). Therefore, we can conclude that dominant alleles play an important role in the formation of these traits.

Broad sense heritability value was higher than narrow sense heritability value for all traits meaning that non-additive gene effect was effective over all traits (Mohamed et al., 2009).

\section{ACKNOWLEDGEMENT}

This project was supported by TÜB TAK (Project No: 1040537)

\section{REFERENCES}

Ado, S.G., Abdullahi, U.S., Usman, I.S., Falaki, A.M. 2006. Progress in Quality Protein Maize Breeding at Samaru, Nigeria. International Plant Breeding Semposium, 20-25 August, Mexico City.

Aguiar, P.A. de., Penna, J.C.V., Freire, E.C., Melo, L.C. 2007. Diallel Analysis of Upland Cotton Cultivars. Crop Breeding and Applied Biotechnology, 7(4): 353359.

Ahuja, S.L., Dhayal, L.S. 2007. Combining Ability Estimates for Yield and Fibre Quality Traits in 4x13 Linextester Crosses of Gossypium hirsutum. De Euphytica, 153: 87-98.

Akbari, L., Khodambashi, M., Houshmand, S. 2013. Genetic Analysis of Phenologic and Productivity Traits in Lentil (Lens culinaris Medik.). International Journal of Agriculture and Crop Sciences, 5(21): 2579-2583.
Ali, B., Iqbal, M.S., Shah, M.K.N., Shabbir, G., Cheema, N.M. 2011. Genetic Analysis for Various Traits in Gossypium hirsutum L. Pakistan J. Agric. Res., 24: 14.

Ali, M.A., Khan, I.A., Awan, S.I., Ali, S., Niaz, S. 2008. Genetics of Fibre Quality Traits in Cotton (Gossypium hirsutum L.). Australian Journal of Crop Science, 2(1): 10-17.

Antoni, J., Scott, V., John, G.K. 1991. RAPD Markers, a New Technology for Genetic Mapping and Plant Breeding. AgBiotech News and Information, 3: 646648.

Baker, R.J. 1978. Issues in Diallel Analysis. Crop Science, 18: 533-536.

Balcı, A., Turgut, . 2006. On Kendilenmiş Atdişi Misır (Zea mays indentata Sturt.) Hattının Diallel Melezlerinde Bazı Tarımsal ve Kalite Özelliklerinin Kalıtımı. Uludag. Üniv. Zir. Fak. Derg., 20(1): 67-83.

Cheatham, C.L., Jenkins, J.N., McCarty, J.C., Watson, C. $\mathrm{Wu}$, J. 2003. Genetic Variances and Combining Ability of Crosses of American Cultivars, Australian Cultivars and Wild Cottons. The Journal of Cotton Science, 7:16-22.

Danehloueipour, N., Yan, G., Clarke, H.J., Siddique, K.H.M. 2007. Diallel Analyses Reveal the Genetic Control of Resistance to Ascochyta Blight in Diverse Chickpea and Wild Cicer Species. Euphytica, 154: 195-205.

Gardner, C.O., Eberhart, S.A. 1966. Analysis and Interpretation of the Variety Cross Diallel and Related Populations. Biometrics, 22: 439-452.

Garg, H.R., Kalsy, H.S. 1988. Inheritance and Association of Some Quantitative Traits in a Diallel Set of Upland Cotton. Indian J. Agric. Sci., 58: 306-8.

Griffing, B. 1956. Concept of General and Specific Combining Ability in Relation to Diallel Crossing Systems. Aust. J. Bio. Sci., 9: 463-493.

Goyal, S.N., Kumar, S. 1991. Combining Ability for Yield Component and Oil Content in Sesame. Indian J. Genet. Plant Breeding, 51: 311-314.

Hayman, B.I. 1954. The Theory and Analysis of Diallel Crosses. Genetics, New Jersey, 39: 789-804.

Jinks, J.L., Hayman, B.I. 1953. The Analysis of Diallel Crosses. Maize Gen. Coop. Newsletter, 27: 48-54.

Karademir, E., Gençer, O. 2010. Combining Ability and Heterosis for Yield and Fiber Quality Properties in Cotton (G. hirsutum L.) Obtained by Half Diallel Mating Design. Notulae Botanicae Horti Agrobotanici Cluj, 38(1): 222-227.

Lukonge, E.P. 2005. Characterization and Diallel Analysis of Commercially Planted Cotton (Gossypium hirsutum L.) Germplasm in Tanzania. Submitted in the Fulfilment of the Requirements for the Degree of Philosophiae Doctor, in the Department of Plant Sciences (Plant Breeding), Faculty of Natural and Agricultural Sciences. University of the Free State Bloemfontein, South Africa. 
Mohamed, G.I.A., Abd-El-Halem, S.H.M., Ibrahim, E.M.A. 2009. A Genetic Analysis of Yield and Its Components of Egyptian cotton (Gossypium barbadense L.) under Divergent Environments. American-Eurasian Journal of Agricultural and Environmental Science, 5(1): 5-13.

Peyman, S. 2012. Diallel Analysis to Study Genetic Parameters of Rice Salinity Tolerance Traits at Germination Stage. SABRAO Journal of Breeding and Genetics, 44(1): 42-57.

Pole, S.P., Kamble, S.K., Madrap, I.A., Sarang, D.H. 2008. Diallel Analysis for Combining Ability for Seed Cotton Yield and Its Components in Upland Cotton (Gossypium hirsutum L.). Journal of Cotton Research and Development, 22(1): 19-22.

Ragsdale, P.I. 2003. Diallel Analysis of Within-Boll Seed Yield Components and Fiber Properties in Upland Cotton (Gossypium hirsutum L.) and Breeding Potential for Heat Tolerance. Texas A\&M University, Doctor of Philosophy, USA.

Rauf, S., Munir, H., Basra, S.M.A., Abdullojon, E. 2006. Combining Ability Analysis in Upland Cotton (Gossypium hirsutum L.). International Journal of Agriculture and Biology, 8(3): 341-343.

Rivera, R., Edwards, K.J., Baker, J.H.A., Arnold, G.M., Ayad, G., Hodgkin, T. 1999. Isolation and Characterization of Polymorphic Microsatellites in Cocos nucifera L. Genome, 42: 668-675.

Saleem, M.Y., Asghar, M., Iqbal, Q., ur-Rahman, A., Akram, M. 2013. Diallel Analysis of Yield and Some Yield Components in Tomato (Solanum lycopersicum L.). Pak. J. Bot., 45(4): 1247-1250.

Şener, O., Kılınç, M., Yağbasanlar, T. 2000. Estimation of Inheritance of Some Agronomical Characters in Common Wheat by Diallel Cross Analysis. Turk. J. Agric. For., 24(2000): 121-127.
Şener, O., Kılınç, M., Yağbasanlar, T., Gözübenli, H., Tiryakioğlu, M. 1999. Buğdayda Bayrak Yaprak Alanının Kalıtımı Üzerinde Araştırmalar. Türkiye 3. Tarla Bitkileri Kongresi, Cilt I, Genel ve Tahıllar, 81-86, Adana.

Townsend, T., Segura, V., Chigeza, G., Penfield, T., Rae, A., Harvey, D., Bowles, D., Graham, I.A. 2013. The Use of Combining Ability Analysis to Identify Elite Parents for Artemisia annua F1 Hybrid Production. PLOS ONE, 8: 4.

Viana, J.M.S., Cruz, C.D., Cardoso, A.A. 2001. Theory and Analysis of Partial Diallel Crosses. Parents and F2 generations. Acta. Sci., 23:627-634

Yao, J.B., Ma, H.X., Ren, L.J., Zhang, P.P., Yang, X.M., Yao, G.C., Zhang, P., Zhou, M.P. 2011. Genetic Analysis of Plant Height and Its Components in Diallel Crosses of Bread Wheat (Triticum aestivum L.). Australian Journal of Crop Science, 5(11): 1408-1418.

Yildırım, M. 2005. A Study on Heredity of Some Agronomical, Physiological and Quality Characteristics in Diallel F1 Offsprings of Selected Six Bread Wheat (Triticum aestivum L.) Cultivars. Department of Field Crops, Institute Natural and Applied Sciences University of Çukurova, Ph. D. Thesis, Adana, 290p.

Zangi, M.R., Jelodar, N.B., Kazemitabar, S.K., Vafaeitabar, M. 2010. Cytoplasmic and Combining Ability Effects on Agro-Morphological Characters in Intra and Inter Crosses of Pima and Upland Cottons ( $G$. hirsutum and $G$. barbadense). International Journal of Biology, 2: 1. 